\title{
ДОСЛІДЖЕННЯ АНАТОМІЧНОЇ БУДОВИ ПІДЗЕМНИХ ОРГАНІВ РОДОВИКА ЛIKAPCЬКОГО (SANGUISORBA OFFICINALIS L. )
}

\author{
() В. В. Кудря ${ }^{1}$, С. М. Марчишин ${ }^{1}$, Л. М. Сіра², В. П. Руденко ${ }^{2}$, І. С. Дахим ${ }^{1}$ \\ ${ }^{1}$ ДВНЗ «Тернопільський державний медичний університет імені І. Я. Горбачевського \\ МОЗ України» \\ ${ }^{2}$ Національний фрармацевтичний університет, Харків \\ svitlanafarm@ukr.net
}

\begin{abstract}
Мета роботи. Родовик лікарський (Sanguisorba officinalis L.) - багаторічна трав'яниста рослина, підземні органи якої здавна використовують у медицині як в'яжучий і кровоспинний засіб. Офріційною медициною використовуються препарати родовика лікарського з кореневища з коренями.

У наукових джерелах недостатньо інформації про фармакогностичне вивчення підземних органів родовика лікарського, тому метою нашої роботи було вивчити анатомічну будову, встановити і зіставити діагностичні ознаки кореневищ і коренів, зібраних восени на першому і другому роках вегетації даного виду.

Матеріали і методи. Виготовлення мікропрепаратів проводили за загальноприйнятими методами. Використовували мікроскоп МС 10 (окуляри X5, X10, 15, об'єктиви X10, X40). Мікрофротограсрії зроблені фротокамерою Samsung PL50.

Результати й обговорення. Кореневище. Підземна частина родовика лікарського представлена багаторічним епігеогенним кореневищем з придатковими коренями. Кореневище поступово дерев'яніє, стає пухким, порожнистим у центрі.

Анатомічна будова кореневища безпучкова. Молоді однорічні кореневища вкриті темно-бурим, поздовжньо зморшкуватим корком. У особин другого року вегетації клітини корка ущільнюються, починають злущуватись. Первинна кора однорічних кореневищ представлена шарами крупноклітинної паренхіми. Ксилема і фрлоема паренхіматизовані, пронизані розширеними радіальними серцевинними променями. В клітинах накопичуються прості і складні крохмальні зерна, часто зустрічаються друзи. Помітно виділяється щільне кільце камбію. Провідна система представлена судинами і ситоподібними трубками. Механічні волокна розташовані відокремлено, невеликими ділянками поблизу судин абоутворюють суцільне кільце поряд з камбієм. Серцевина з міжклітинниками, паренхімні клітини з крохмальними зернами і друзами кальцій оксалату.

Корені мають вторинну будову. Корок шаруватий, кільця 3 коричневим або жовтуватим вмістом чергуються 3 кільцями світлішими або безбарвними. Зона камбію багатошарова, темніша, добре помітна. Ксилема промениста. Трахеїди пористі. Серцевинних променів багато. У клітинах наявні дрібні прості овальні та округлі крохмальні зерна, друзи та поодинокі призматичні або багатогранні кристали кальцію оксалату.

У дворічних коренів зовнішній шар корка товстий, темно-коричневий, з тріщинами; чітко виділяються річні кільця ксилеми, серцевинних променів багато, волокна лубу чисельні, здерев'янілі.

Висновки. Досліджено анатомічну будову підземних органів родовика лікарського, зібраних на першому і другому роках вегетації. Виявлено мікроскопічні діагностичні ознаки кореневищ і коренів.
\end{abstract}

Ключові слова: родовик лікарський; кореневище; корені; анатомічна будова; діагностичні ознаки.

Вступ. Родовик лікарський (Sanguisorba officinalis L.) - багаторічна трав'яниста рослини родини Rosaceae, яка зростає по заплавних луках, торфовищах, узліссях, по берегах річок, біля драговин, в основному, у західних і північних районах України [1, 2]. Підземні органи родовика здавна використовують у медицині як в'яжучий і кровоспинний засіб при внутрішніх кровотечах, для зміцнення ясен при пародонтозі, при геморої, лямбліозному холециститі, проносі. Офріційною медициною використовуються препарати родовика лікарського кореневища 3 коренями
(Sanguisorbae rhizoma cum radicibus) [3, 4, 5, 6], як в'яжучі і кровоспинні засоби. Препарати мають виражені бактерицидні властивості та застосовується при запаленнях порожнини рота та горла, для змазування ясен при гінгівіті, стоматиті, в гінекології (трихомонадний кольпіт). Виявлено значний бактерицидний вплив відварів підземних органів родовика лікарського на мікроорганізми кишкової групи, що спричиняють дизентерію, черевний тиф, паратифи А і B. Швидкий ефект дає зовнішнє застосування відвару кореневища та коренів родовика при гострому гній-

ISSN 2312-0967. Фармацевтичний часопис. 2017. № 2 
Фітохімічні дослідження

Phytochemical researches

ному кон'юнктивіті. Препарати родовика застосовують для промивання гнійних ран, примочок при екземах, дерматитах і дерматозах, нейродермітах, трофрічних виразках, променевих дерматитах [2, 7]. 3 кореневищ 3 коренями рослини виготовляли бактерицидним препарат «Санальбін» [7].

У наукових джерелах недостатньо інформації відносно фрармакогностичного вивчення підземних органів родовика лікарського, в тому числі й мікроскопічних досліджень, тому метою нашої роботи було вивчити анатомічну будову, встановити і зіставити діагностичні ознаки кореневищ і коренів, зібраних восени на першому і другому роках вегетації даного виду.

Матеріали і методи. Виготовлення мікропрепаратів проводили за загальноприйнятими методами [8, 9]. Анатомічну будову кореневища та коренів аналізували за методикам мікроаналізу на поперечних зрізах та поздовжніх зрізах досліджуваних об'єктів. Ви- користовували мікроскоп МС 10 (окуляри X5, X10, 15, об'єктиви X10, X40). Мікрофротограсрії зроблені фротокамерою Samsung PL50.

Результати й обговорення. Кореневище. Підземна частина родовика лікарського представлена багаторічним епігеогенним кореневищем із придатковими коренями. Кореневище формується у процесі поступового перетворення осей надземних пагонів на підземні завдяки їх засипанню і втягуванню в ґрунт. Розміри кореневища збільшуються, розташування в ґрунті змінюється від вертикального (фраза цвітіння) до горизонтального (фаза плодоношення), коли головний корінь відмирає і активно розвиваються потужні придаткові корені. Кореневище поступово дерев'яніє, стає пухким, порожнистим у центрі.

Анатомічна будова кореневища (рис. 1) безпучкова. Молоді однорічні кореневища вкриті 4-5-рядним темно-бурим, поздовжньо зморшкуватим корком. У особин
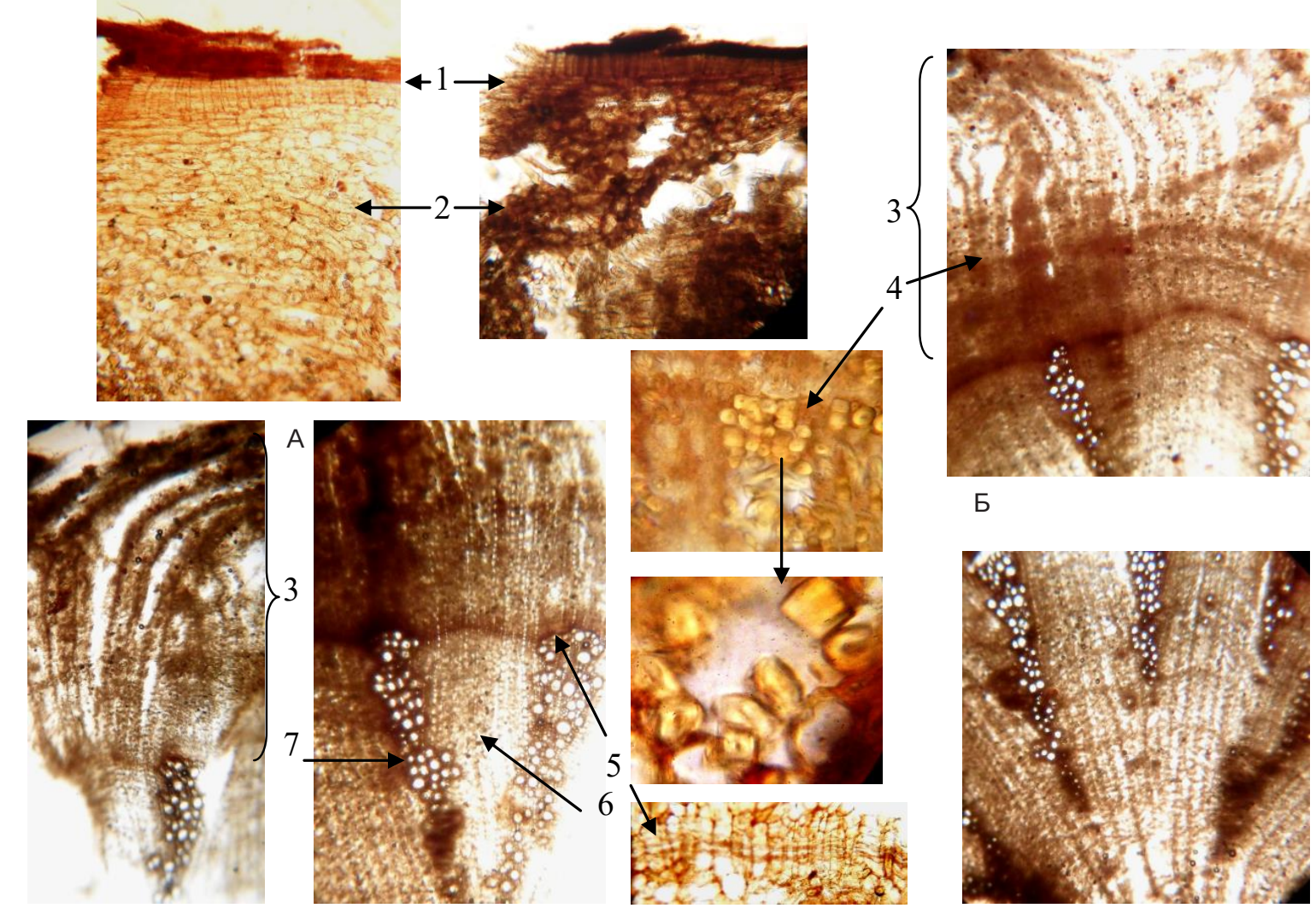

B
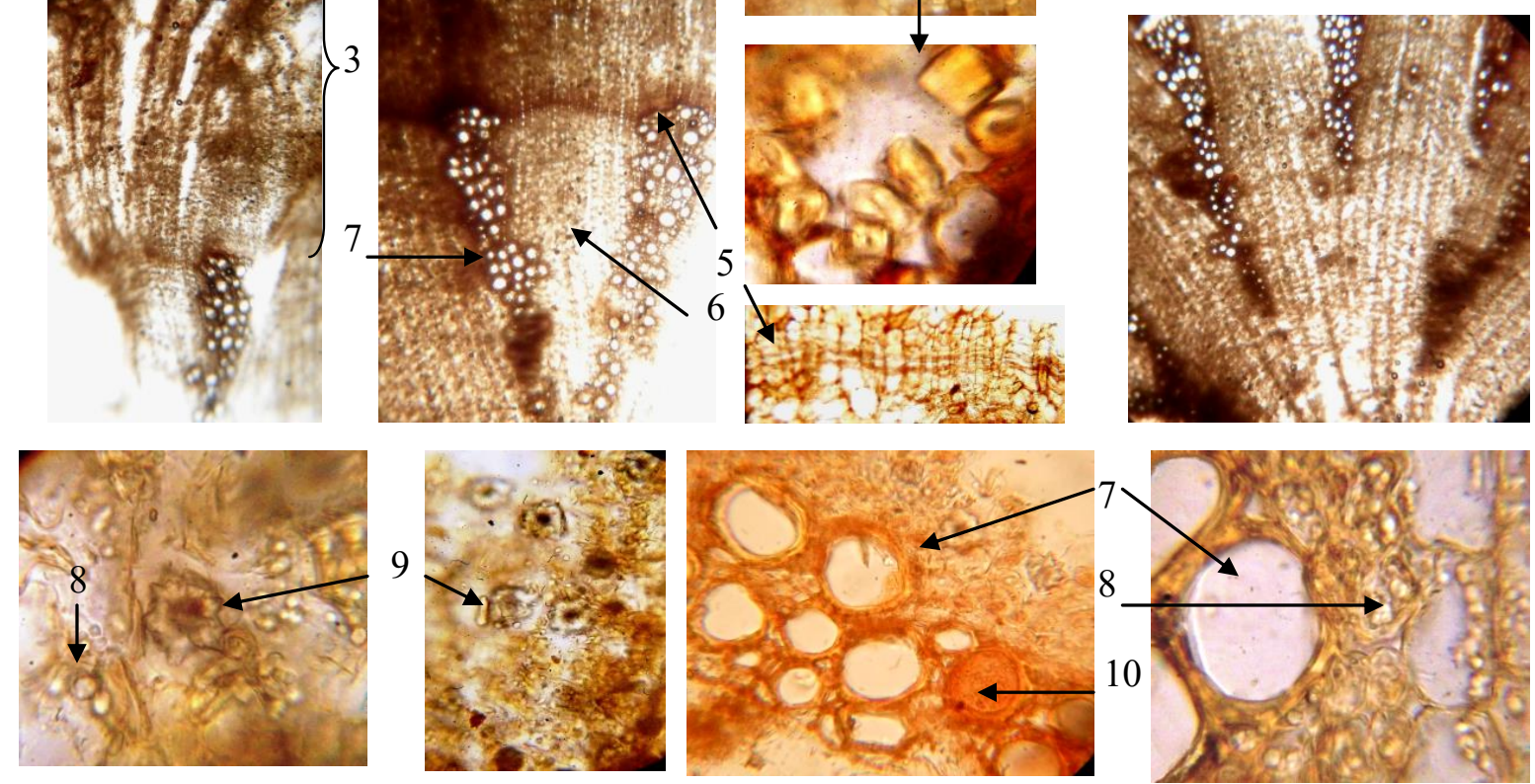

Рис. 1. Фрагменти поперечних зрізів однорічних (А) і дворічних (Б) кореневищ:

1 - перидерма, 2 - корова паренхіма, 3 - вторинна кора, 4 - волокна, 5 - камбій, 6 - серцевинні промені, 7 судини ксилеми, 8 - паренхіма 3 крохмальними зернами, 9 - друзи, 10 - клітини 3 дубильними речовинами.

ISSN 2312-0967. Pharmaceutical review. 2017. № 2 
другого року вегетації клітини корка ущільнюються, починають злущуватись. Товщина перидерми збільшується за рахунок утворення нових шарів корка.

Первинна кора однорічних кореневищ представлена шарами крупноклітинної паренхіми, яка 3 віком стає пухкою, з великими міжклітинниками. Поступово в більш глибоких шарах первинної кори старіючих кореневищ закладається фрелоген, виникають нові шари корка, які відтісняють первинну кору, і вона відмирає. Найбільшого розвитку набуває паренхіма вторинної кори з великими порожнинами.

Ксилема і фрлоема також значно паренхіматизовані, пронизані розширеними радіальними, вигнутозвивистими серцевинними променями. Число рядів клітин збільшується від 5-6 на першому році, до 3040 - на другому. В клітинах накопичуються прості і складні крохмальні зерна, часто зустрічаються друзи. Помітно виділяється суцільне 2-7-шарове щільне кільце камбію. Над камбієм ситоподібні трубки розташовуються чітко одна над одною. Провідна система ксилема представлена судинами, розміщеними променисто або згрупованими по 3-10. Механічні волокна розташовані відокремлено, невеликими ділянками поблизу судин або утворюють суцільне кільце поряд 3 камбієм. В період старіння нараховується 2-3 механічні кільця, що проходять не лише у провідній частині, а й в променях. Інколи ділянки волокон оточені окорковілими клітинами.

Серцевина з міжклітинниками, паренхімні клітини містять велику кількість крохмальних зерен (біля 6-8 мм в діаметрі) і друз кальцій оксалату. Надалі спостерігається окорковіння і часткове відмирання клітин перимедулярної серцевини і ксилеми, накопичення друз.

Дубильні речовини виявляються в паренхімі усіх частин кореневища, а також у ситоподібних трубках і судинах.

Корені родовика лікарського мають вторинну будову, вкриті перидермою з багатошаровим корком, клітини якого розташовані радіальними стовпчиками (рис. 2). Корок шаруватий, кільця 3 коричневим або жовтуватим вмістом чергуються 3 кільцями світлішими або безбарвними. Клітини перисрерійних шарів тангентально видовжені, а внутрішніх - паренхімні, менш щільні. Поступово верхня частина перидерми злущується, утворюються тріщини.

Корова паренхіма добре розвинена. На межі 3 перидермою її клітини тангентально видовжені, 3 потовщеними оболонками, а більш заглиблені - округло-овальні. Ділянки провідних елементів лубу широкі, променисті (рис. 2) чергуються з розширеними або однорядними верхівками серцевинних променів 3 темним вмістом. Значна частина клітин має потовщені целюлозні оболонки, решта клітин з менш потовщеними оболонками утворює невеликі групи або тангентально видовжені ділянки. Волокнисті механічні елементи із частково або цілком здерев'янілими оболонками розташовані по 1-3 або більш чисельними групами. На поперечних зрізах (рис. 3, А) форма волокон округла, еліптична або округло-кутаста, розміри порожнин варіюють. На поздовжніх зрізах (рис. 3, Б) клітини недовгі, пористі, із загостреними кінцями, інколи зігнуті. У окремих волокон спостерігаються поперечні перетяжки (рис. 3, Б).

Зона камбію багатошарова, темніша, добре помітна. Ксилема промениста, в ній домінують пористі й драбинчасті судини з короткими або видовженими члениками, частіше з косими поперечними перорораціями (рис. 4). Трахеїди пористі. Серцевинні промені чисельні, добре помітні, однорядні або багаторядні розширені, здебільшого, доходять до центру органа. Серед паренхіми серцевинних променів 3 целюлозними потовщеними або тонкими оболонками утворюються окремі вузькі судини (рис. 4, Г)

У клітинах паренхіми усіх частин кореня наявні дрібні прості овальні та округлі крохмальні зерна, друзи та поодинокі призматичні або багатогранні кристали кальцію оксалату (рис. 5). Іноді в окремих
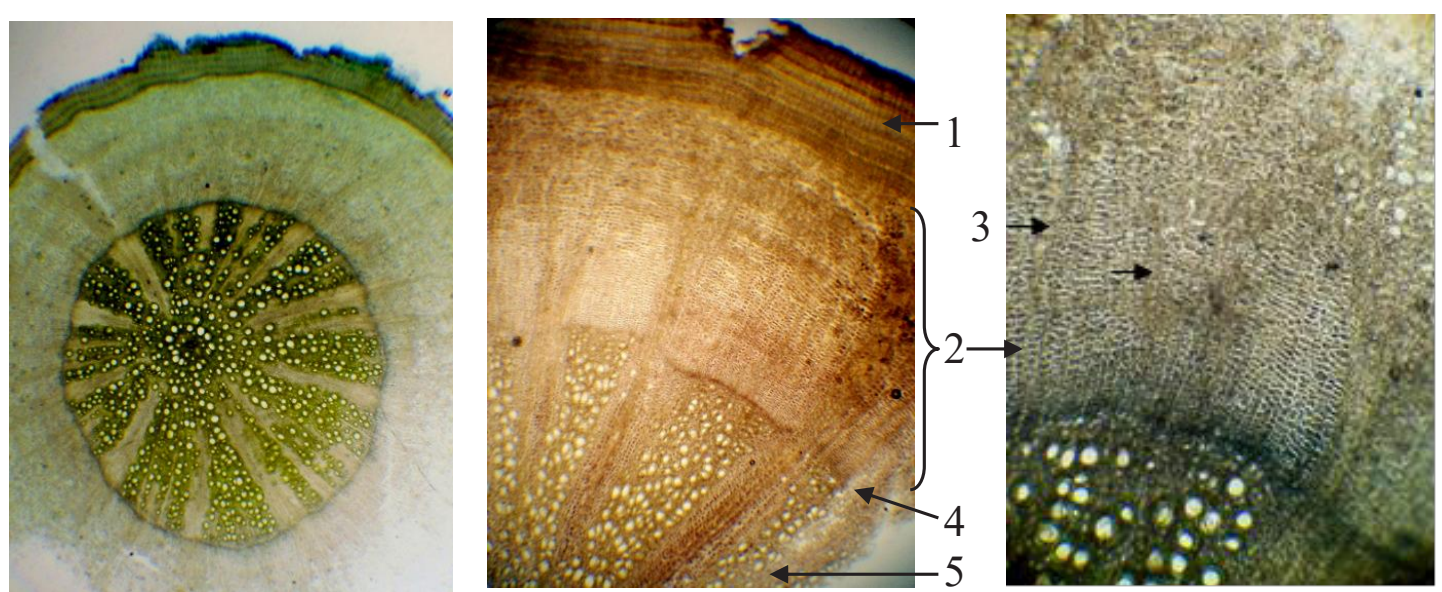

Рис. 2. Поперечні зрізи кореня першого року:

1 - перидерма, 2 - вторинна кора, 3 - серцевинні промені, 4 - камбій, 5 - ксилема.

ISSN 2312-0967. Фармацевтичний часопис. 2017. № 2

Рис. 3. Луб'яні волокна на поперечних (А) і поздовжніх (Б) зрізах однорічного кореня. 
Фітохімічні дослідження

Phytochemical researches
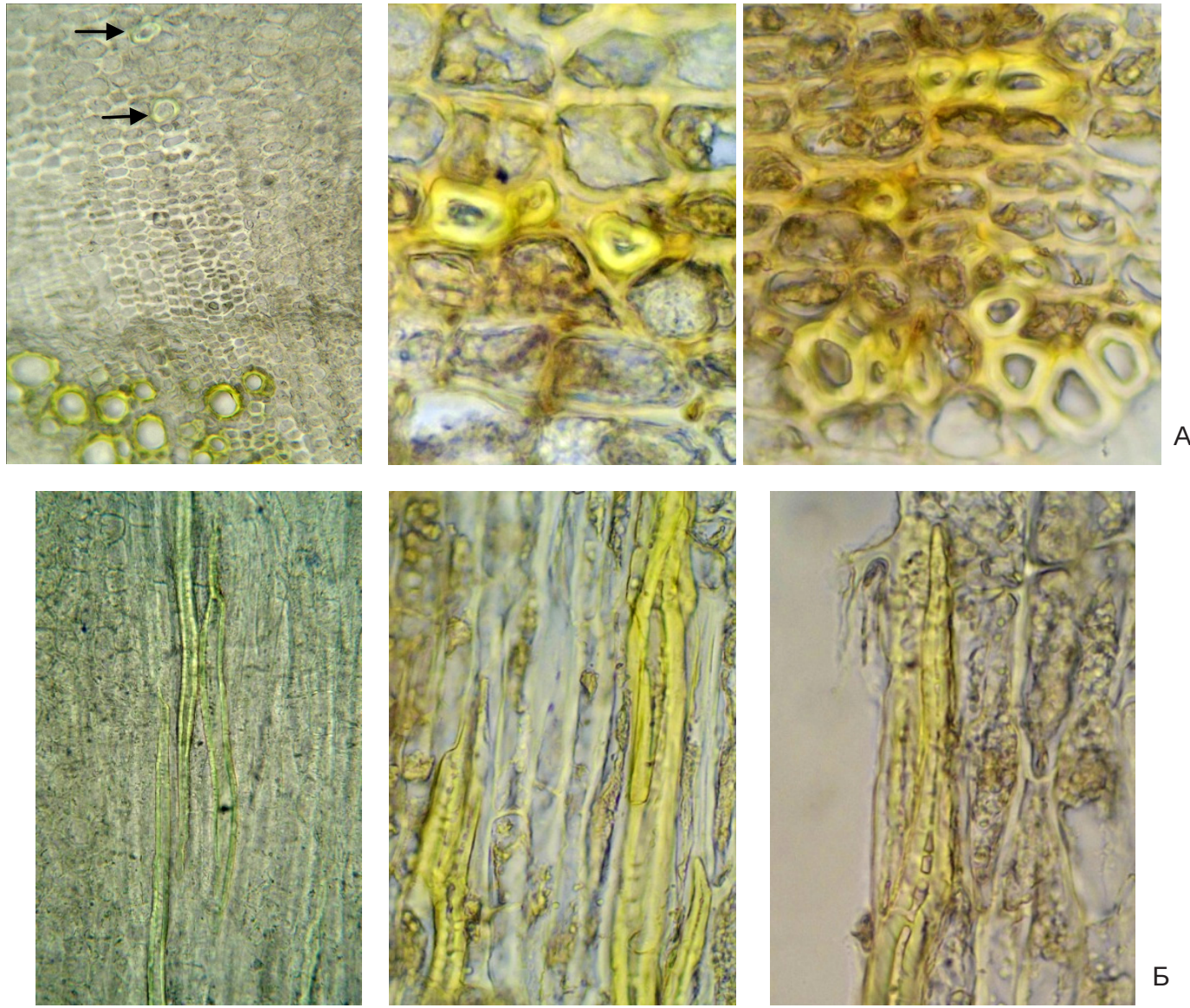

Рис. 3. Луб'яні волокна на поперечних (А) і поздовжніх (Б) зрізах однорічного кореня.

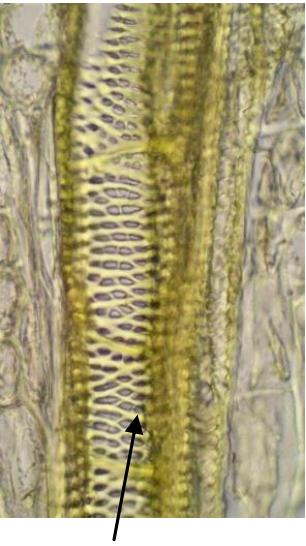

1

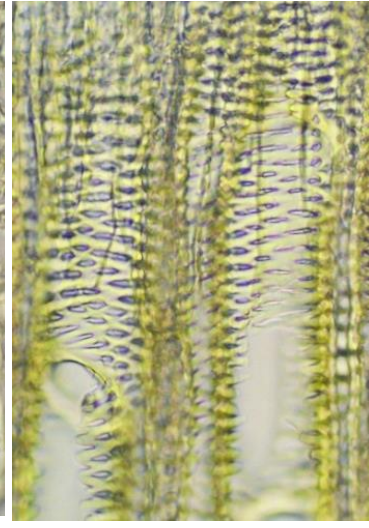

Б

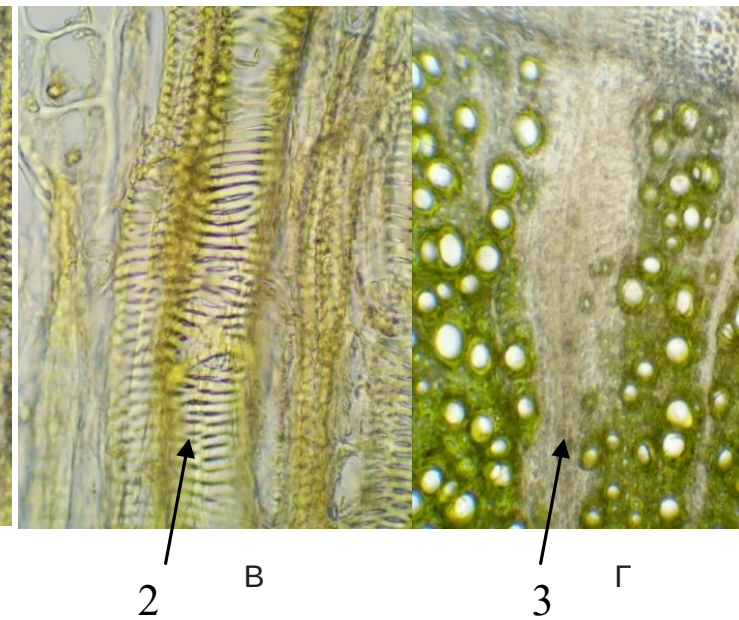

Рис. 4. Судини на поздовжніх (А, Б, В) і поперечному (Г) зрізах ксилеми однорічного кореня: 1 - пористі судини, 2 - драбинчасті судини, 3 - серцевинні промені з поодинокими судинами.

клітинах серцевинних променів міститься коричнева гомогенна речовина (рис. 5, В).

У дворічних коренів (рис. 6) зовнішній шар корка товстий, темно-коричневий, з тріщинами; чітко виділяються річні кільця ксилеми, в яких збільшується частка лібриформу; серцевинних променів багато, вони, переважно, однорядні; волокна лубу чисельні, здерев'янілі, розташовані поодинці, групами та переривчастими кільцями по всій товщині фрлоеми (рис. 6). 


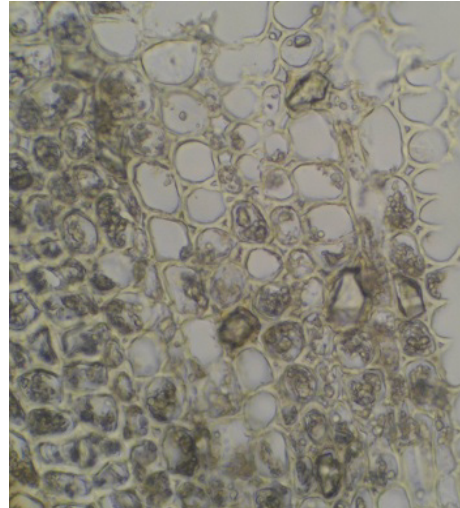

A

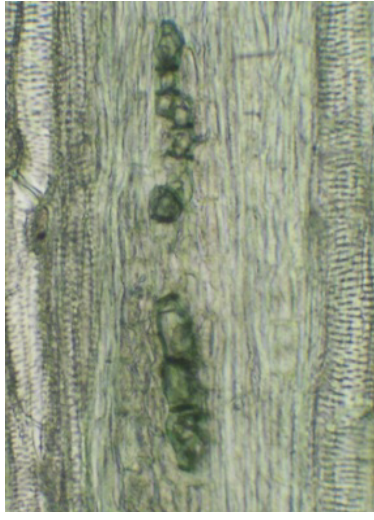

Б

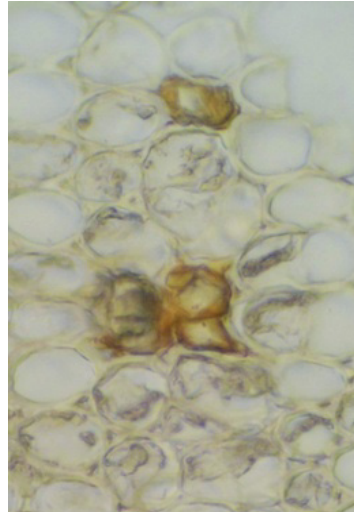

B

Рис. 5. Включення паренхіми коренів:

А - крохмальні зерна і кристали в паренхімі фрлоеми і серцевинних променів (поперечний зріз); Б - кристали в паренхімі ксилеми (поздовжній зріз); В - кристали і пігментовані клітини у серцевинних променях.
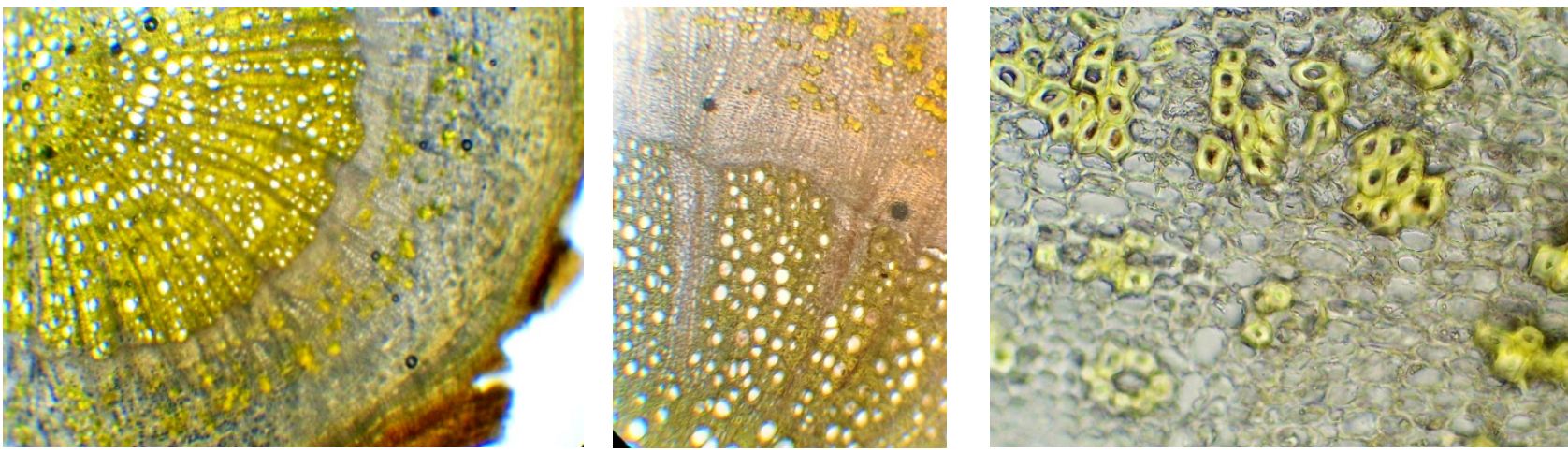

Рис. 6. Поперечні зрізи коренів другого року життя.

Висновки. Досліджено анатомічну будову підземних органів родовика лікарського, зібраних на першому і другому роках вегетації. Виявлено мікроскопічні діагностичні ознаки кореневищ і коренів.

Кореневище: анатомічна будова безпучкова; корок молодих кореневищ зморшкуватий, темно-бурий, 4-5-рядний, зрілих - ущільнений, багаторядний, місцями злущений; паренхіма кори однорічних кореневищ крупноклітинна, щільна, зрілих - 3 міжклітинниками; ксилема і фрлоема пронизані радіальними, вигнуто-звивистими серцевинними променями; серцевина пухка; в паренхімі провідної системи і серцевини містяться крохмальні зерна і друзи кальцію оксалату, кількість яких значно збільшується у кореневищах другого року життя.
Корені: мають вторинну будову; у однорічних корок багатошаровий, в ньому кільця клітин з коричнюватим або жовтуватим вмістом чергуються 3 шарами світліших або безбарвних клітин; корова паренхіма розвинена; широка зона фрлоеми поділена серцевинними променями; наявні волокна зі слабо здерев'янілими оболонками; добре помітна зона камбію; ксилема промениста, трахеїди пористі, судини пористі та драбинчасті, іноді судини утворюються серед клітин серцевинних променів; у клітинах паренхіми кори, лубу і серцевинних променів наявні дрібні прості крохмальні зерна, друзи та поодинокі призматичні або багатогранні кристали кальцію оксалату. Корені другого року значно здерев'янілі, містять багато друз, з більш широкою ксилемою і товстою, потрісканою перидермою.

ISSN 2312-0967. Фармацевтичний часопис. 2017. № 2 


\title{
ИССЛЕДОВАНИЕ АНАТОМИЧЕСКОГО СТРОЕНИЯ ПОДЗЕМНЫХ ОРГАНОВ КРОВОХЛЕБКИ ЛЕКАРСTВЕННОЙ (SANGUISORBA OFFICINALIS L.)
}

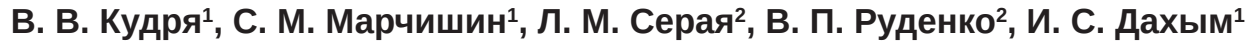 \\ ${ }^{1} Г$ ГУЗ «Тернопольский государственный медицинский университет имени И. Я. Горбачевского Мз \\ Украины» \\ ${ }^{2}$ Национальный фрармацевтический университет, Харьков \\ svitlanafarm@ukr.net
}

Цель работы. Кровохлебка лекарственная (Sanguisorba officinalis L.) - многолетнее травянистое растение, подземные органы которого издавна используют в медицине как вяжущее и кровоостанавливающее средство. Офрициальной медициной используются препараты кровохлебки лекарственной из корневища с корнями.

В научных источниках недостаточно инорормации о фрармакогностическом изучении подземных органов кровохлебки лекарственной, поэтому целью нашей работы было изучить анатомическое строение, установить и сопоставить диагностические признаки корневищ и корней, собранных осенью на первом и втором годах вегетации данного вида. Материалы и методы. Изготовление микропрепаратов проводили за общепринятыми методами. Использовали микроскоп МС 10 (окуляры X5, X10, 15, объективы X10, X40). Микрофотографрии сделаны фротокамерой Samsung PL50. Результаты и обсуждение. Корневище. Подземная часть кровохлебки лекарственной представлена многолетним эпигеогенным корневищем с придаточными корнями. Корневище постепенно деревенеет, становится рыхлым, полым в центре. Анатомическое строение корневища безпучковое. Молодые однолетние корневища покрыты темнобурой, продольноморщинистой пробкой. В растений второго года вегетации клетки пробки уплотняются, начинают слущиваться. Первичная кора однолетних корневищ представлена слоями крупноклеточнойпаренхимы. Ксилема и фрлоэма паренхиматизированные, пронизаны расширенными радиальными сердцевинными лучами. В клетках накапливаются простые и сложные крахмальные зерна, часто встречаются друзы. Заметно выделяется плотное кольцо камбия. Проводящая система представлена сосудами и ситообразными трубками. Механические волокна расположены небольшими участками вблизи сосудов или образуют сплошное кольцо рядом с камбием. Сердцевина с межклетниками, паренхимные клетки с крахмальными зернами и друзами кальция оксалата.

Корни имеют вторичную структуру. Пробка слоистая, кольца с коричневым или желтоватым содержимым чередуются с кольцами светлыми или бесцветными. Зона камбия многослойная, темнее, хорошо заметна. Ксилема лучистая. Трахеиды пористые. Сердцевинных лучей много. В клетках имеются мелкие простые овальные и округлые крахмальные зерна, друзы и отдельные призматические или многогранные кристаллы кальция оксалата. В двухлетних корней внешний слой пробки толстый, темно-коричневый, с трещинами; четко выделяются годичные кольца ксилемы, сердцевинных лучей много, волокна луба многочисленные, одревесневшие. Выводы. Исследовано анатомическое строение подземных органов кровохлебки лекарственной, собранных на первом и втором годах вегетации. Выявлены микроскопические диагностические признаки корневищ и корней.

Ключевые слова: кровохлебка лекарственная; корневище; корни; анатомическое строение; диагностические признаки.

\section{INVESTIGATION OF THE ANATOMICAL STRUCTURE OF UNDERGROUND ORGANS OF SANGUISORBA OFFICINALIS L.}

\author{
${ }^{1}$ V. V. Kudrya, ${ }^{1}$ S. M. Marchyshyn, ${ }^{2}$ L. M. Sira, ${ }^{2}$ V. P. Rudenko, ${ }^{1}$. S. Dakhym \\ 1. Horbachevsky Ternopil State Medical University \\ ${ }^{2}$ National University of Pharmacy, Kharkiv \\ svitlanafarm@ukr.net
}

The aim of the work. Greater burnet (Sanguisorba officinalis L.) is a perennial herbaceous plant; the underground organs are used in medicine as astringent and antihemorrhage remedy. Medicines from rhizomes and roots of S. officinalis are used in official medicine.

In scientific references there is not enough information about pharmacognostic features of subterranean organs of greater burnet. So, the aim of out work was to study anatomy structure and to determine the main diagnostic signs of rhizomes and roots of the plant.

Materials and Methods. Micro preparations were prepared using conventional methods. Microscope MC 10 (oculars X5, X10, X15, objectives X10, X40) was used. Micro photos were made with photo camera Samsung PL 50.

Results and Discussion. Rhizome. The underground part of greater burnet is represented by perennial epigeogenic rhizome with adventitious roots. Rhizome becomes woody, loose and cave gradually.

ISSN 2312-0967. Pharmaceutical review. 2017. № 2 
Anatomical structure of rhizome is characterized by the absence of bundles. Young rhizomes are covered by dark reddish-brown longitudinally wrinkled cork. Mature samples consolidated cork cells that appear to be exfoliated. Primary bark of young rhizomes is represented by the layers of grand-cellular parenchyma. Xylem and phloem are also significantly filled with parenchyma, permeated with expanded radial medullary rays. Simple and complex starch grains are accumulated in cells, druses are often seen. Dense ring of cambium is clearly determined. Vascular system is represented by vessels and sieve tube elements. Mechanical fibers are located separately arranged into small areas near the vessels or form continuous ring near the cambium. The core includes intercellular spaces, parenchymatous cells with starch grains and calcium oxalate druses.

Root of greater burnet has secondary structure. The cork is multilayered; the rings are with brownish or yellowish content and also with several layers of cells without coloured content. The cambium zone is multilayered, dark and clearly visible. Xylem appears as radial. Tracheids are porous. Medullary rays are numerous.

Simple oval and roundish small starch grains, druses and single prismatic or multilayered crystals of calcium oxalate are present in cells.

The outer layer of cork of mature roots is thick, dark-brown with cracks; rings of xylem are clearly visible, medullary rays and bast fibers are numerous.

Conclusions. The study of peculiarities of anatomical structure of young and mature underground organs from Sanguisorba officinalis was performed; the typical microscopic diagnostic features were determined.

Key words: Sanguisorba officinalis L.; rhizomes; roots; anatomical structure; diagnostic features.

\section{Список літератури}

1. Определитель высших растений Украины / Д. Н. Доброчаева, М. И. Котов, Ю. Н. Прокудин и др. 2 изд. - Киев : Фитосоциоцентр, 1999. - С. 170-171.

2. Марчишин С. М. Лікарські рослини Тернопільщини / С. М. Марчишин, Н. О. Сушко. - Тернопіль : Навчальна книга - Богдан, 2007. - С. 232-234.

3. Родовик лікарський [Електронний ресурс] // Вікіпедія. - Режим доступу інфрорм: https://www.google.com.ua/ search?q

4. Державна Фармакопея України : в 3 т. / Державне підприємство «Український науковий срармакопейний центр якості лікарських засобів». - 2-е вид. - Харків : Державне підприємство «Український науковий фрармакопейний центр якості лікарських засобів», 2014. - T. 3. - C. 438-439.

5. Практикум 3 ідентисрікації лікарської рослинної

\section{References}

1. Dobrochayeva DN, Kotov MI, Proskudin YuN. The determinant of higher plants of Ukraine. [Определитель высших растений Украины] Kiev: Phytosociocenter; 1999. p. 170-1. Russian.

2. Marchyshyn SM, Sushko NO. Medicinal plants of Ternopil region [Лікарські рослини Тернопільщини] Ternopil: Educational book - Bohdan; 2007. Ukrainian.

3. Greater burnet. [Weblink https://www.google.com.ua/ search?q]. [Visited on 27 March, 2017]. Ukrainian.

4. State Pharmacopoeia of Ukraine. 3 vol. / State Enterprise Ukrainian Scientific Pharmacopoeial Center of Medicines Quality. - $2^{\text {nd }}$ edn. Kharkov: State Enterprise Ukrainian Scientific Pharmacopoeial Center of Medicines Quality, 2014; 3:438-9. Ukrainian.

5. Kovalov VM, Marchyshyn SM, Khvorost OP, Isakova TI, Kovalova AM, Popova NV et al. Workshop in medicinal plant material identification [Практикум з ідентифрікації сировини : навч. посіб. / [В. М. Ковальов, С. М. Марчишин, О. П. Хворост та ін.]; за ред. В. М. Ковальова, С. М. Марчишин. - Тернопіль : ТДМУ, 2014. - С. 184-185.

6. Практикум по фрармакогнозии : учеб. пособие для студ. вузов / В. Н. Ковалев, Н.В.Попова, В.С.Кисличенко и др.; под общей редакцией В. Н. Ковалева. - Х. : Золотые страницы: Изд-во НФаУ, 2003. - С. 199.

7. Товстуха $€$. С. Золоті рецепти української народної медицини / Є. С. Товстуха. - К. : KM Publishing, 2010. С. 335-336.

8. Справочник по ботанической микротехнике. Основы и методы / [Р. П. Барыкина, Т. Д. Веселова, А. Г. Девятов и др.]. - М. : Изд-во МГУ, 2004. - 312 с.

9. Фурст Г. П. Методы анатомо-гистохимического исследования растительных тканей / Г. П. Фурст. - М. : Наука, 1979. - 154 с. лікарської рослинної сировини]. Ternopil: Ternopil State Medical University; 2014. Ukrainian.

6. Kovalov VM, Popova NV, Kyslychenko VS, Isakova TI, Zhuravel IO, Stepanova SI et al. Workshop on Pharmacognosy. [Практикум по фрармакогнозии] Kharkiv: Golden Pages; 2003. Ukrainian.

7. Tovstuha YeS. Golden prescriptions of Ukrainian folk medicine [Золоті рецепти української народної медицини] Kyiv: KM Publishing; 2010. Ukrainian.

8. Barykina RP, Veselova TD, Devyatov AG, Dzhalilova HH, Ilyina GM, Chubatova NV. Reference book on botany microtechnique. Fundamentals and methods [Справочник по ботанической микротехнике. Основы и методы] Moscow: MSU Publishing; 2004. Russian.

9. Furst G P. Methods of anatomically-histological investigation of plants' tissues [Методы анатомо-гистохимического исследования растительных тканей] Moscow: Science; 1979. Russian.

Отримано 11.04.2017

ISSN 2312-0967. Фармацевтичний часопис. 2017. № 2 